\title{
BEACH NOURISHMENT IN CHINA: STATUS AND PROSPECTS
}

\author{
Feng Cai ${ }^{1}$, Robert G Dean ${ }^{2}$, Jianhui Liu ${ }^{1,3}$
}

\begin{abstract}
Many beach nourishment projects have been performed in China over the last 2 decades since the first project was completed in 1990 in Hong Kong. The history and distribution of beach nourishment in China is summarized in this paper. Considering the development of nourishment design and public perceptions, the history of beach fill in China can be summarized into 3 stages. In general, this paper shows the characteristics of 4 types of nourishment projects based on different environmental conditions, 4 typical nourished sites for each type were selected and described in detail respectively. Considering the current research status in China, recommendations and suggestions for future development are outlined, including such aspects as construction of more and larger projects, development of beach management strategies, a beach nourishment manual, research efforts on numerical models for sediment transport and post-project monitoring and evaluation.
\end{abstract}

Keywords: beach nourishment; beach design; China

\section{INTRODUCTION}

Beach nourishment comprises the placement of large quantities of good quality sand on the beach to advance it seaward (Dean, 2002). The principal approach to protecting coastal property and maintaining recreational beaches in the United States today is beach nourishment. It also has been applied successfully to beach stabilization and development of beaches where none were present in many countries including the Netherlands, Japan, Spain, Germany, France, etc.

China has $18000 \mathrm{~km}$ of mainland coastline, about 1/3 of them consist of sandy beaches, and $70 \%$ of sandy beaches are experiencing coastal erosion (Xia, 1996). Coastal erosion has become a major concern for future socio-economic developments in coastal cities (Cai et al., 2009). Traditionally, the response to coastal erosion is mainly "hard engineering" such as seawalls, groins and breakwaters. While these coastal constructions provide protection to upland properties, the long-term monitoring of coastal changes around such structures frequently shows adverse environmental effects, in the vicinity as well as further away on adjacent shores (Hamm, 2002). Due to the potential adverse effects on the beach and dune system from "hard engineering", more and more governors and coastal engineers recognized the necessity of a "soft engineering" approach to maintain sustainable development of coastal environment. Therefore, beach nourishment, as a new appropriate technology, was first studied in the western and developed countries, and recently the nourishment concept has gradually spread to many developing countries including China.

\subsection{History}

As a new technology, beach nourishment was first introduced into China in early 1990s. The first nourishment project in China was performed in Repulse Bay, Hong Kong, in 1990. Repulse Bay, which was depleted during World War II by sand mining, has been nourished by pumping sea floor sediments onshore (Leatherman, 1996). In mainland China, the earliest nourishment project was completed in 1994 along Xinghai Bay, Dalian city. Considering the development of nourishment design consideration and public perceptions, the history of beach fill in China can be summarized into 3 stages as follows:

(1) Seasonally sand placement on beach in summer (before 1990).

To meet beach tourism needs in summer season, sand has been placed to increase beach width for recreational purposes, as it has been done in the city of Qingdao (Zhang, 2002). Due to lack of adequate consideration of beach morphodynamic processes and the general coastal environment, sand was transported away quickly and needed to be replaced sooner than expected.

(2) Small scale nourishment without comprehensive engineering study and design (1990 2005).

During this period, the cities of Qingdao and Dalian have implemented several small scale beach nourishment projects combined with constructions like groins and jetties intended to stabilize the beach and minimize maintenance (Song et al., 2005), but half of them failed due to rapid erosion or muddy silt deposition.

(3) Beach nourishment to protect the coast, improve environment and increase tourism (2005 present).

Owing to the public awareness of the importance of coastal protection and natural coastal

\footnotetext{
${ }^{1}$ Third Institute of Oceanography, State Oceanic Administration, Xiamen, 361005, China

${ }^{2}$ Department of Civil and Coastal Engineering, University of Florida, Gainesville, Florida, 32611, USA

${ }^{3}$ College of Marine Geo-Science, Ocean University of China, Qingdao, 266003, China
} 
ecosystem and beach recreation, governments now pay more attention to and invest in "soft engineering”. Since 2005, beach nourishment has increased substantially in China, and many projects of larger scale have been performed. During this period, some advances on project design, monitoring and evaluation procedures have been made.

\subsection{Nourishment Distribution}

China started its rational beach nourishment program in the early 21st century, with some projects performed in Qinhuangdao city (Zhang et al., 2008; Yang et al., 2009), Xiamen Island (Cao et al., 2009; Wang et al., 2009) and Hainan Island (Ji et al., 2007). The distribution of main nourishment projects in China is shown in Figure 1. Nourishment practices are commonly performed in coastal cities which are famous for their holiday resorts and where tourism has grown tremendously. Also, the economic development in these cities is generally better than the others.

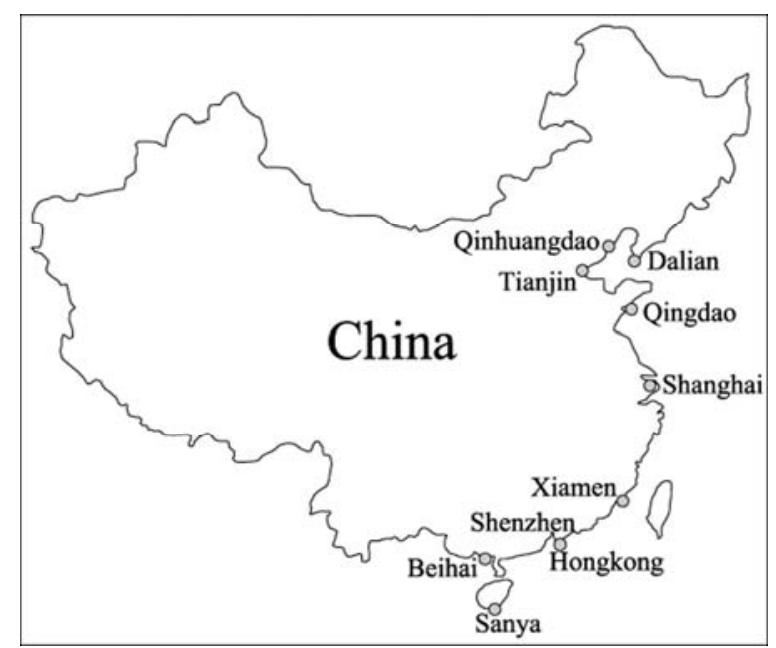

Figure 1. Distribution of main nourishment events in China.

\section{STATUS OF NOURISHMENT PROJECTS}

\subsection{Types}

Based on the difference of environmental conditions and coastal geomorphology where projects have been constructed, beach nourishment projects in China can be broadly classified into 4 types. Example cases of each type are described in more detail as follows:

(1) Beach nourishment to design a straight beach: Case of Xiangshan-Changweijiao Beach, Xiamen Island.

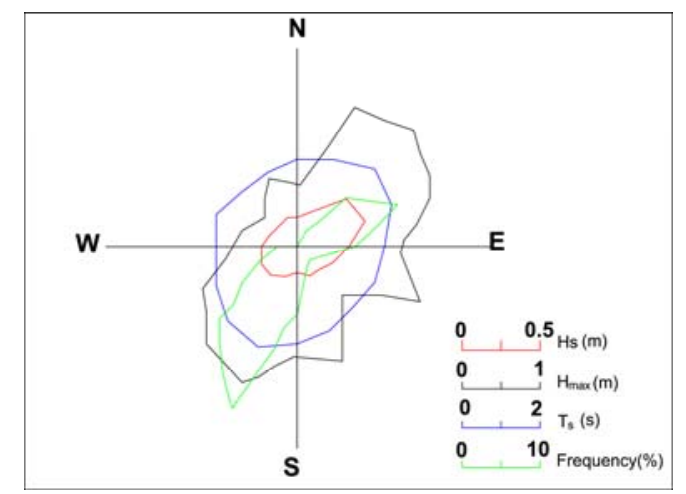

Figure 2. Wave rose diagram around the sea area from 2005 to 2006.

Xiangshan-Changweijiao beach with a length of $1.5 \mathrm{~km}$ is located in the southeast of Xiamen Island. Differing from the other bay beaches around Xiaman Island, the configuration of coastal stretch in Xiangshan-Changweijiao is nearly straight. Before the 1990s, there was a beautiful beach with widths of about 10 to $50 \mathrm{~m}$, a beach slope angle generally of $5^{\circ} \sim 6^{\circ}$, and beach sediment typically 
consisting of fine sand. Owing to the human activities such as sand mining and offshore aquaculture, the beach finally disappeared and only left muddy deposits and debris on shoreface. According to the urban planning of Xiamen Island, a beach would be restored to protect the coast and for recreational purposes.

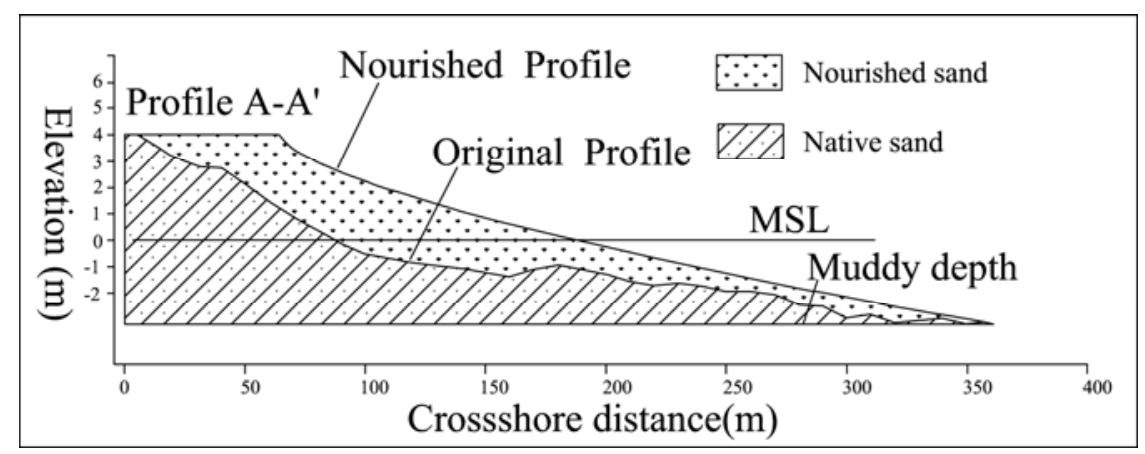

Figure 3. Nourished profile design for Xiangshan-Changweijiao beach.

Xiangshan-Changweijiao beach is characterized by a macro-tide with mean tidal range of 3.99m. Wave measurements were conducted to obtain the wave data by using Nortek AWAC (Acoustic Wave and Current), for the period from April 15, 2005 to April 18, 2006. The resulting wave rose diagram is shown in Figure 2. The dominant wave direction is from NE E and SSW SW, wave action is weak with Hs of $0.33 \sim 0.45 \mathrm{~m}$, and the direction of net longshore sediment transport is from NE to SW.

Based on the equilibrium beach profiles proposed by Bruun (1954) and Dean (1987) and the macro tide condition, a nourished cross beach profile was designed (Figure 3). Beach design and construction parameters are listed in Table 1.

\begin{tabular}{|l|l|l|}
\hline \multicolumn{3}{|c|}{ Table 1. beach design and construction parameters } \\
\hline Parameter & Design & Construction \\
\hline Volume & $740,000 \mathrm{~m}^{3}$ & $820,000 \mathrm{~m}^{3}$ \\
Beach length & $1.5 \mathrm{~km}$ & $1.5 \mathrm{~km}$ \\
Sand size & $0.5 \mathrm{~mm}$ & $0.3-0.66 \mathrm{~mm}$ \\
Dry beach width & $30-80 \mathrm{~m}$ & $50-80 \mathrm{~m}$ \\
Beach slope & $2^{\circ}$ & $3.5^{\circ}$ \\
\hline
\end{tabular}

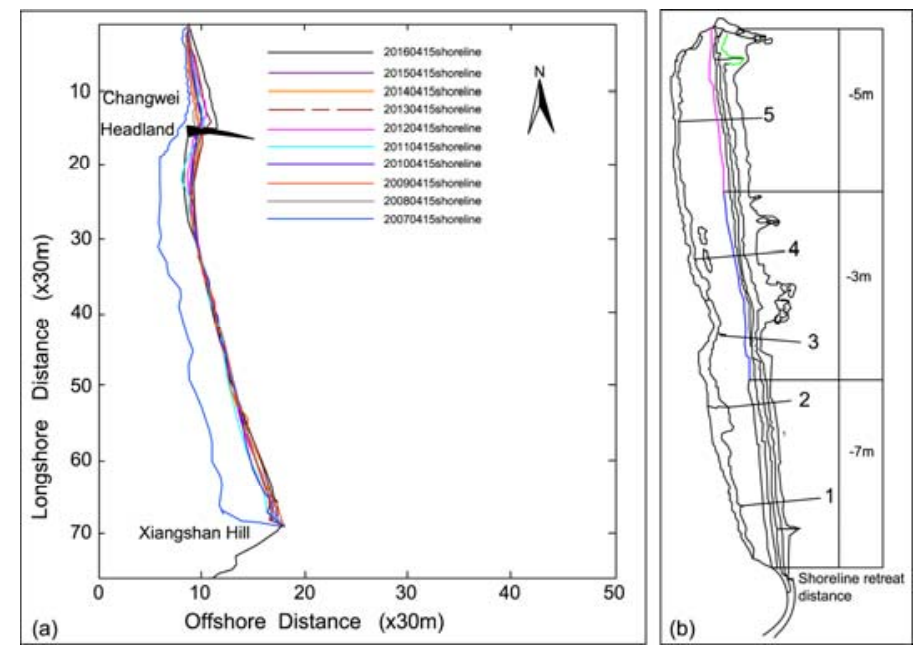

Figure 4. Shoreline change prediction and monitoring result. Shoreline change from 2007 to 2016 is shown in Panel a (left), shoreline retreat for the first winter half year is shown in Panel b (right). Numbers indicate positions of monitoring profiles.

A one-line model was used to predict shoreline change after implementation and the predicted shoreline change from 2007 to 2016 is shown in Figure 4a. The monitoring results of shoreline retreat (Figure 4b) for the first winter half year after nourishment agrees well with the predictions. Based on the recession distance, the nourished beach can be broadly divided into 3 segments from the north to the south, the average recession in the north part was $5 \mathrm{~m}, 3 \mathrm{~m}$ in the middle and $7 \mathrm{~m}$ in the south, 
respectively. Beach profile monitoring indicated that morphological change mainly happened in the upper inter-tidal zone and accretion in the lower zone (see Figure 5). The planform of nourished beach became stable after 2 years following project completion (Figure 6).

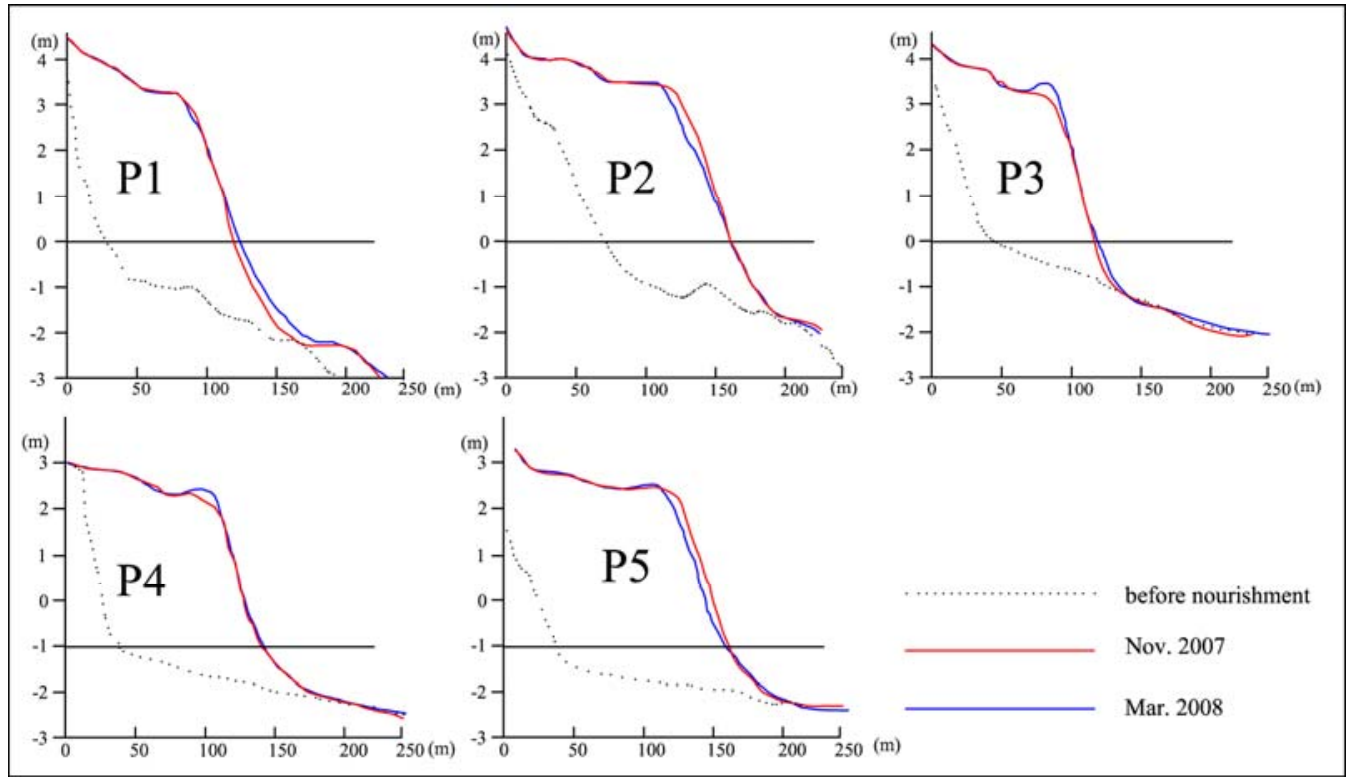

Figure 5. Beach profile change in the first winter after nourishment.

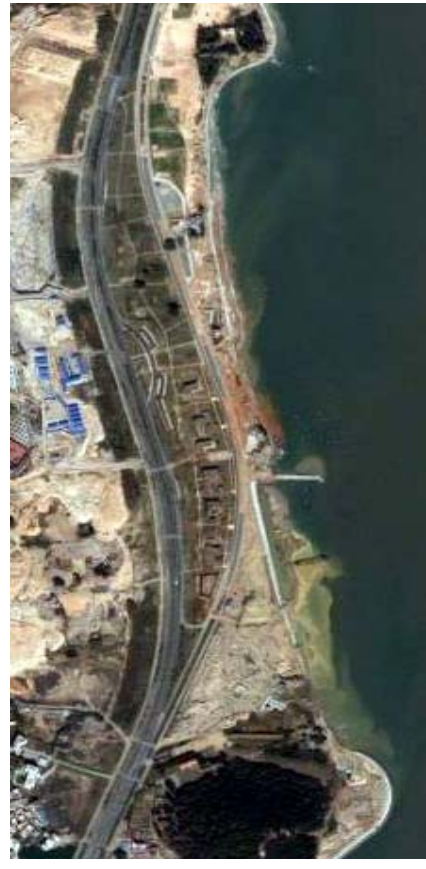

April .2006

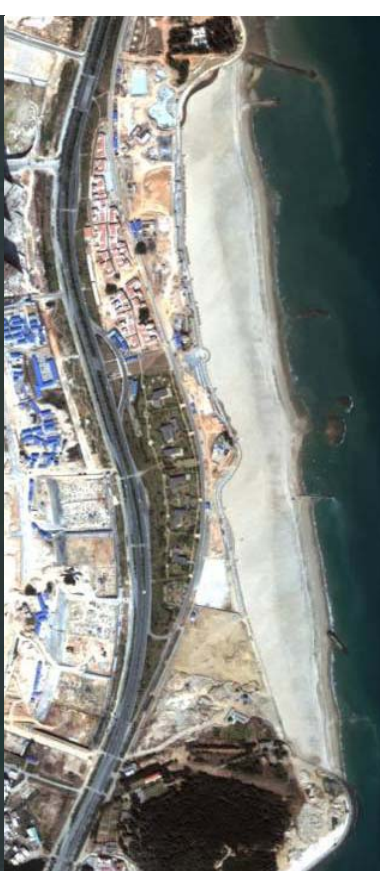

Nov .2007

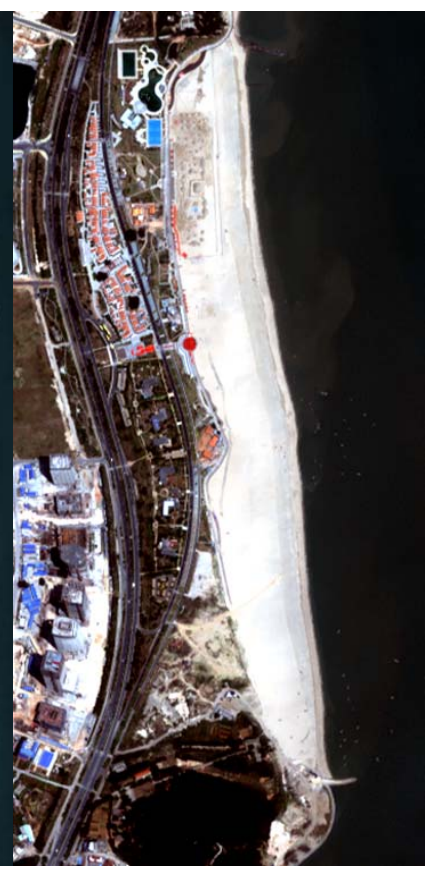

Oct .2009

Figure 6. Comparison of satellite images of nourished beach at different time.

After this project was completed, more and more tourists were attracted and many important activities were conducted on this beach. Considering the demand of the larger beach space for major activities such as beach volleyball contests, beach football games and open-air concerts et al., a wider dry beach is needed, therefore the Xiamen municipal government approved funding to widen the beach by about $20 \mathrm{~m}$. To stabilize this wider beach, a groin was constructed at the north limit of the beach (Figure 6).

(2) Beach nourishment in a bay: Case of West Beidaihe Beach.

West Beidaihe beach is reasonably close to Beijing and is a very famous summer vacation destination. This beach is located at the southwest of Qinhuangdao, northeast of Dai river mouth and is 
characterized by a $3.5 \mathrm{~km}$ length bay beach, with a headland at the northeast end of the beach, where a jetty was previously located but was removed in 2002. The beach has experienced erosion since 1950s with an average retreat rate of $0.6 \mathrm{~m} /$ year, the beach slope has steepened from $1^{\circ}$ to $3^{\circ}$, and the intertidal zone sediment has coarsened from a median-diameter of $0.35 \mathrm{~mm}$ in 1964 to $0.56 \mathrm{~mm}$ in 1995 (Feng et al, 1999). The main causes of coastal erosion are due to continued decrease in sediment supply and manual extraction of sand and gravel.Man-made reservoirs in some rivers sharply reduced the sediment supply and beach sand was mined for construction of roads, bridges and houses.

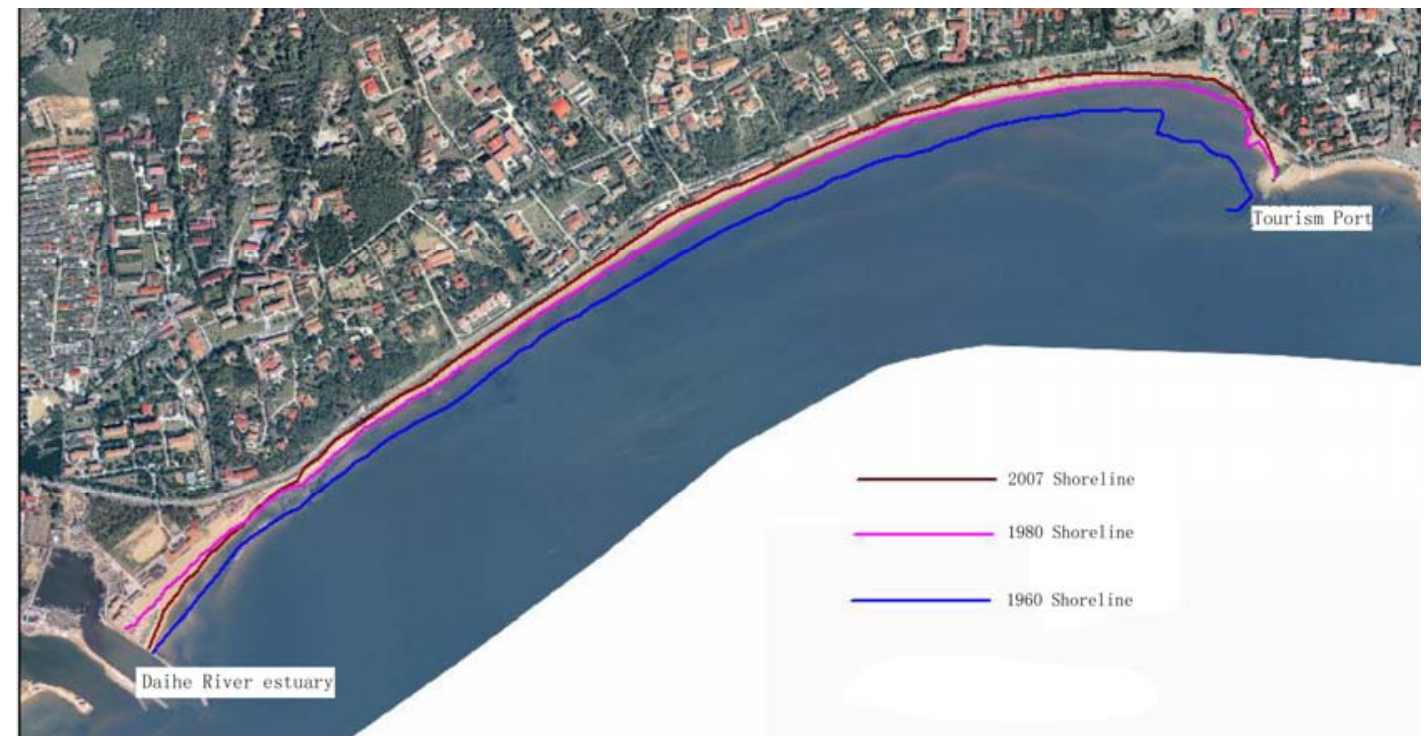

Figure 7. Shoreline change of western Beidaihe beach from 1960 to 2007.

In order to meet the rising demand of bathing places on west beach in summer season. A small-scale emergency project was carried out by Qinhuangdao Mineral Resource and Hydrogeological Brigade from May 2 to June 12, 2008. In this project, a scheme of beach nourishment with supporting submerged breakwaters was included in this first stage (Figure 8).

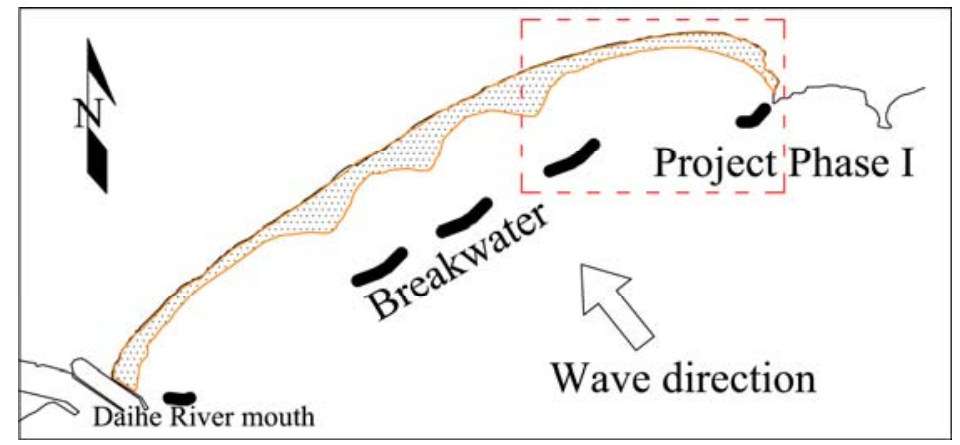

Figure 8. General nourishment and its first Phase practice design.

Hydrodynamic conditions of this area were monitored from 2005 to 2006. The results document an average wave height of $0.6 \mathrm{~m}$, significant wave height $(\mathrm{Hs})$ of $0.97 \mathrm{~m}$, dominant wave direction coming from SE-E, average wave period $(\mathrm{T})$ of $2.6 \mathrm{~s}$, and average wave length $(\mathrm{L})$ of $11.6 \mathrm{~m}$. The longshore current direction is from SW to NE. Using the wave data mentioned above, an application of the coastal modeling system (SMC), which was developed by University of Cantabria (UC) and the Environmental Ministry of Spain (MMA), successfully simulated the wave field transformation, longshore current and longshore sediment transport (Figures 9a, 9b, 9c) taking the construction of submerged breakwater into account. Modeling result shows that the submerged breakwater can help to stabilize a nourished sandy bay beach. Additionally, GENESIS modeling of shoreline evolution (Figure 10) also predicted the project feasibility. 

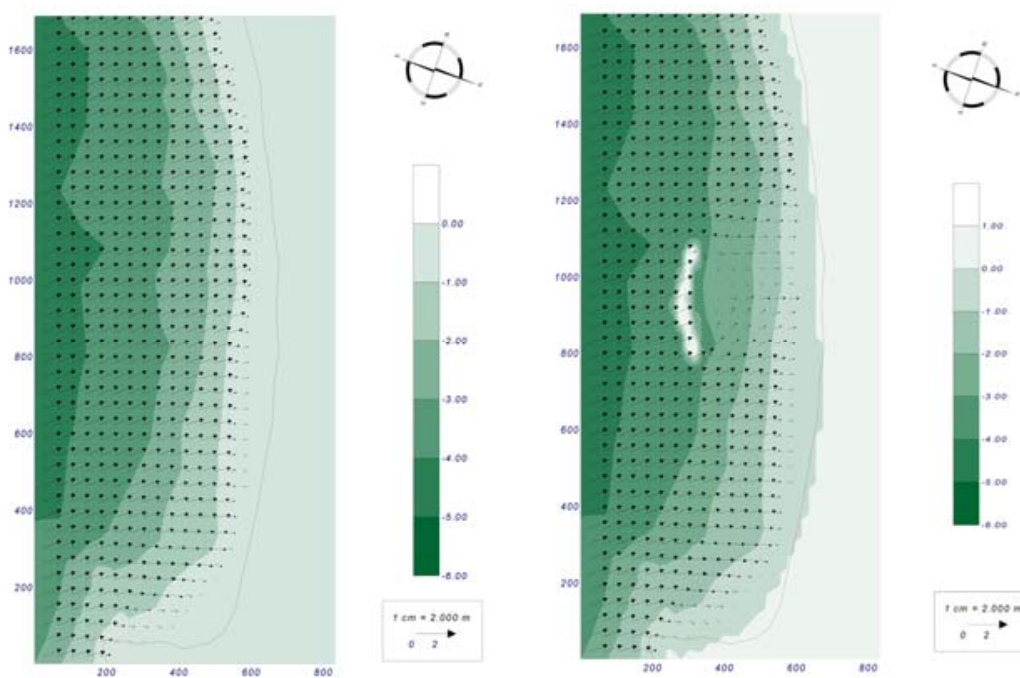

a
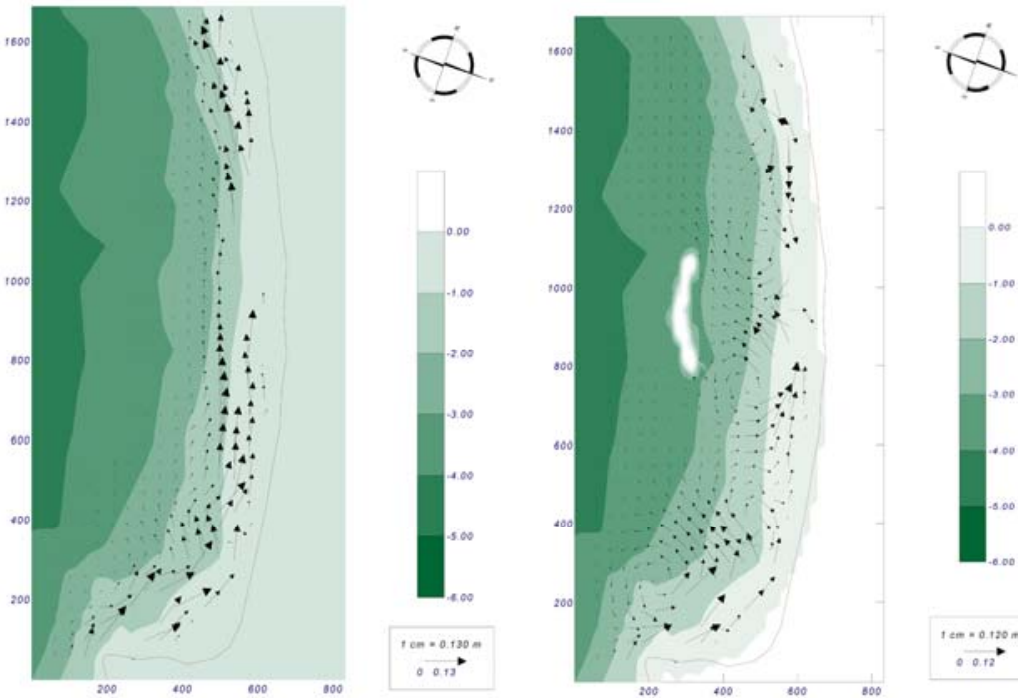

b
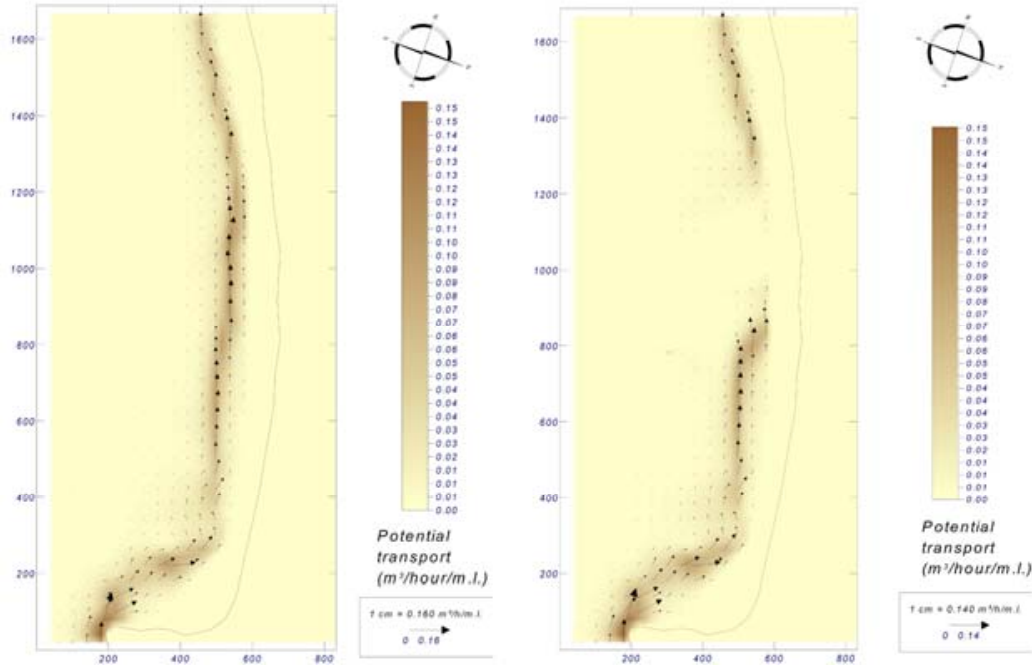

$\mathrm{C}$

Figure 9. Comparison of wave field, longshore current and longshore sediment transport before and after the construction of submerged breakwater.a.wave height increase and direction change due to wave diffraction induced by submerged breakwater,b.currents converge from different directions behind the breakwater, c.sediment was transported from opposite directions and should deposit behind the breakwater. 


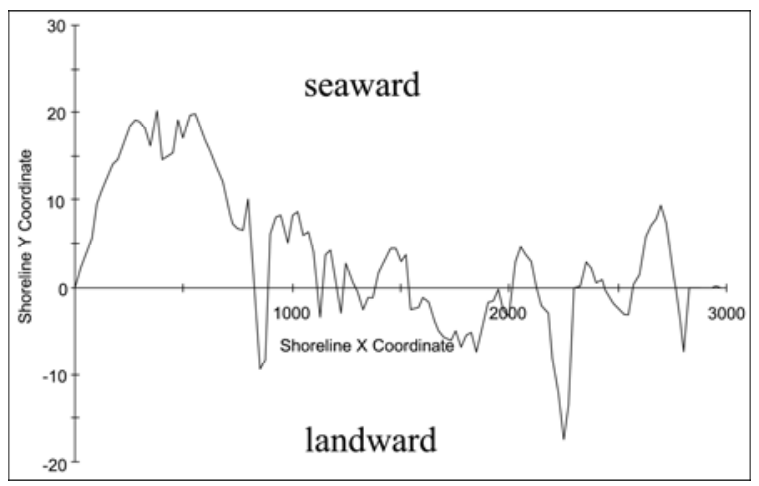

Figure 10. GENESIS modeling of Shoreline evolution.

After Phase I of the project was performed, shoreline change monitoring has been conducted once a month, with results shown in Figure 11 indicating stability of the nourished beach.

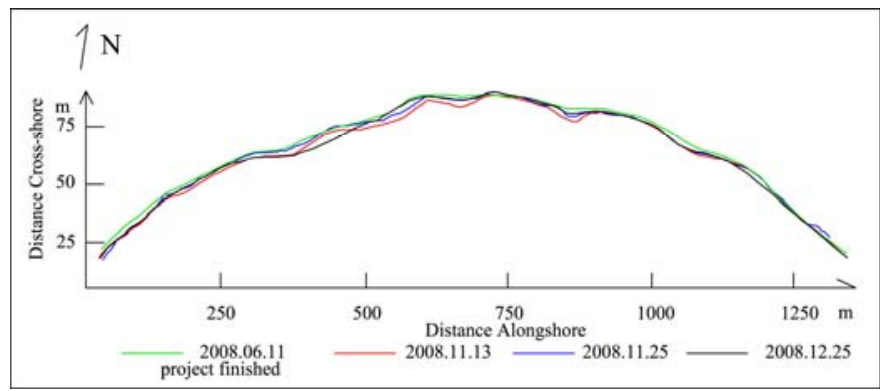

Figure 11. Shoreline change after beach nourishment.

(3) Beach nourishment along an armored coast: Case of east Gulangyu Island Beach.

Gulangyu Island is located off the coast of Xiamen in Fujian Province. As a favorite tourist attraction, Gulangyu Island is renowned for its beaches, winding roads and its varied architecture. The beach on the east coast of this island was mainly composed of fine sand before 1998. Owing to the construction of a seawall and two ports (Sanqiutian port in the north and ferry port in the south) along the east coast (Figure 12), part of the upper beach was occupied and the beach profile integrity was destroyed. Waves could wash up against the seawall and reflect back towards the ocean with more energy to transport the sand on the beach in front of seawall, finally beaches lost finer sediment leaving coarse sand and gravel on shoreface (Figure 14). Therefore, a decision was made by the managers to nourish the beach for the purpose of restoring tourism attractiveness along the coast.

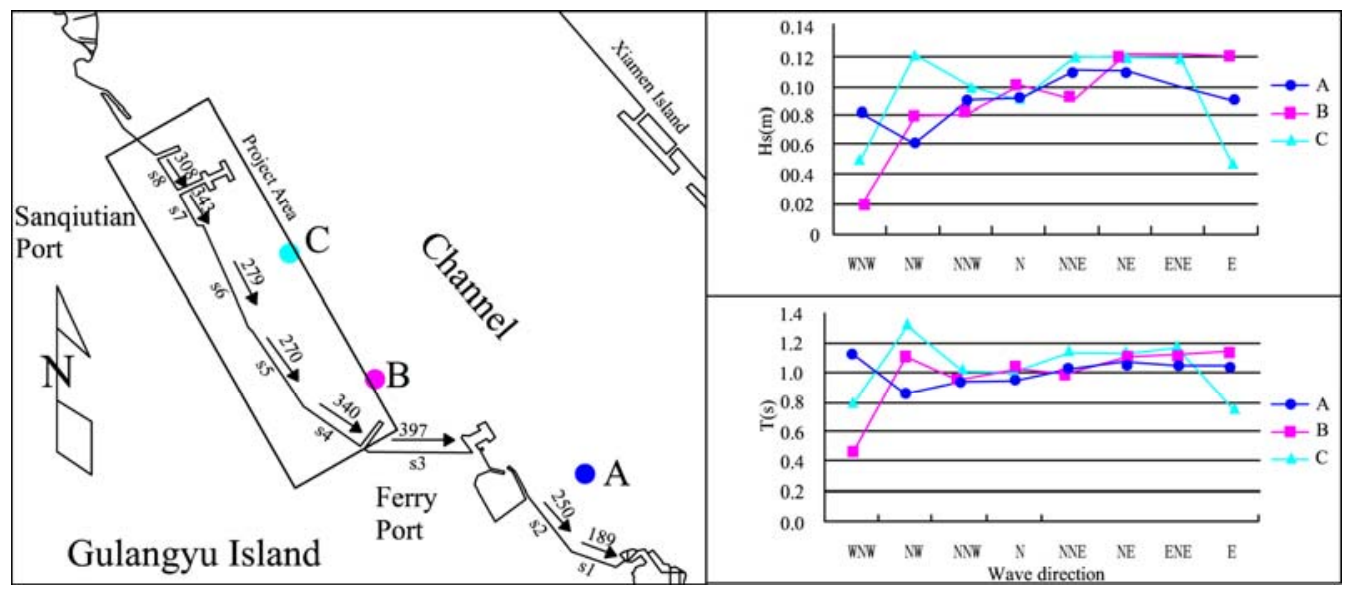

Figure 12. Pr oject area along east coast in Gulangyu Island. Points $A, B$ and $C$ show the wave calculation points. Wave conditions in different locations are showed on left. Longshore sediment transport $\left(\mathrm{m}^{3} / \mathrm{a}\right)$ for each stretch is listed along the coastline. 
Wave measurements at three locations documented mild wave action along the coast (Figure 12). A tidal current survey in 2000 showed that the maximum ebb was $61 \mathrm{~cm} / \mathrm{s}$, maximum flood was $87 \mathrm{~cm} / \mathrm{s}$, average ebb was $47 \mathrm{~cm} / \mathrm{s}$ for a dominant direction of $125^{\circ}$ and average flood was $60 \mathrm{~cm} / \mathrm{s}$ for a dominant direction of $322^{\circ}$ in the channel. Longshore sediment transport was also calculated, net longshore sediment transport is about $300 \mathrm{~m}^{3} / \mathrm{a}$ with a direction from SW (Figure 12). Based on the nourished beach profile design and selected sediment grain size (Figure 13), the project was performed in February 2007 with main execution parameters are shown in Table 2. Three years after the beach has been nourished, slight erosion was found on the upper beach; however, the entire beach profile was generally stable (Figure 14).
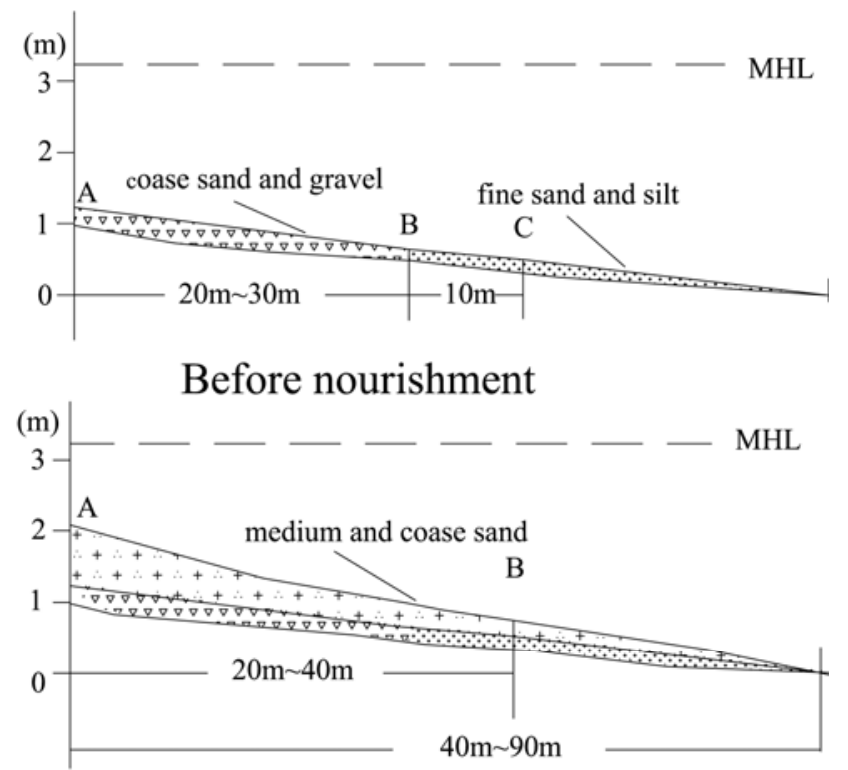

\section{After nourishment}

Figure 13. Beach profile design and sediment fill.

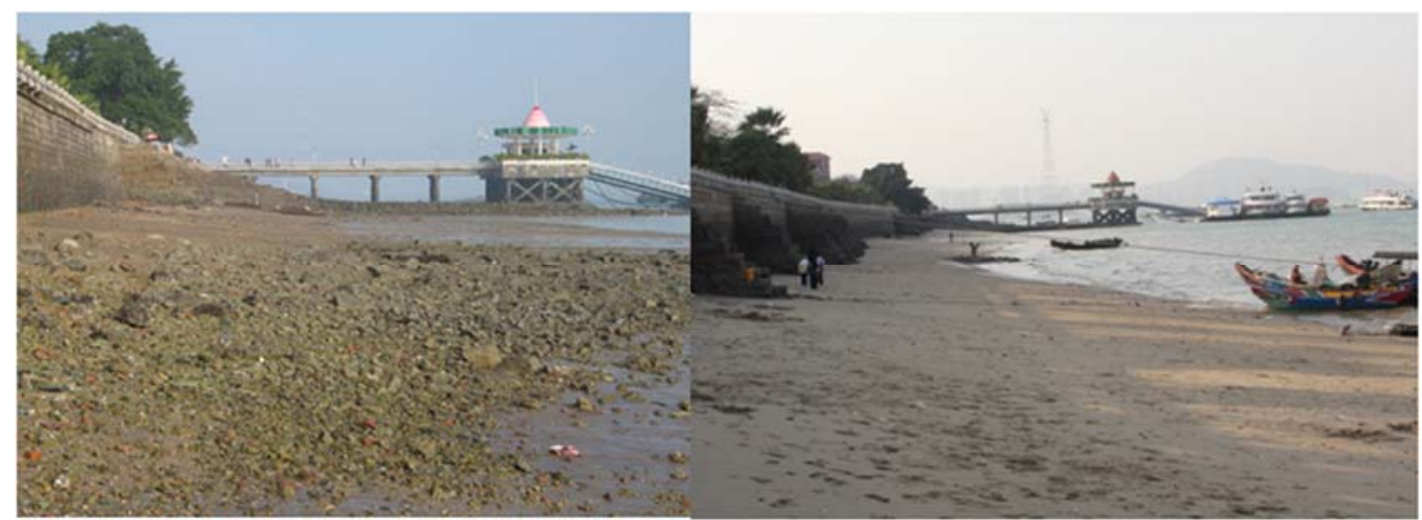

Before nourishment(21,August 2006)

After nourishment(10, April 2010)

Figure 14. Comparison of the east beach in Gulangyu Island before and after nourishment.

(4) Artificial beach along muddy coast: Case of Jinshan Beach.

Considering the tourism demand, city governments need to build sufficiently wide beaches for recreational purposes since the number and total length of good quality beaches are inadequate especially for cities along muddy coasts. Therefore, some artificial beaches were constructed along the coast where no beaches has existed in the past. Among these the most famous are Dongjiang beach in Tianjin and Jinshan Bay beach in Shanghai (figure 15). The population of each city (Tianjin and Shanghai) is more than 10 million; thus there are many potential users of sandy beaches. 


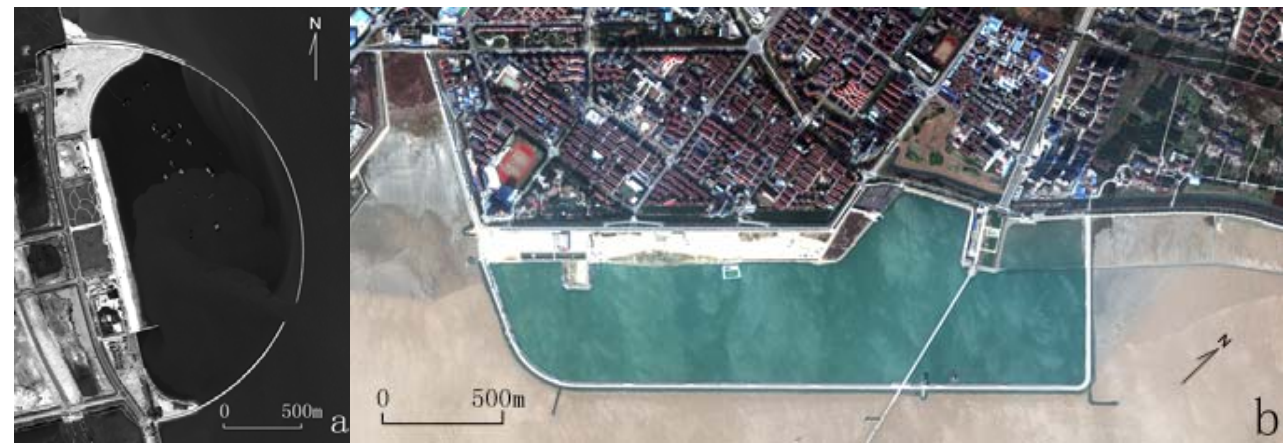

Figure 15. Artificial beach along muddy coast. a. Dongjiang artificial beach in Tianjin, b. Jinshan artificial beach in Shanghai.

Artificial beaches along muddy coasts are entirely different from beach nourishment projects along sandy coasts with respect to design considerations and environmental conditions. The case of Jinshan beach is described in more detailed below.

Jinshan beach is located at the southeast of Shanghai City and faces the East China Sea and Hangzhou Bay. The sea around has a yellow coloration due to high suspended sediment concentration. In order to block off the outside suspended muddy sediment, a $3.3 \mathrm{~km}$ long, $5.4 \mathrm{~m}$ high dike was built to enclose $1.5 \mathrm{~km}^{2}$ of sea area, after mud and sand in the sea water is deposited in a sedimentation tank, the water will be introduced into another reservoir to receive special treatment, finally, producing clean water to maintain the bathing beach which was formed by 120,000 tons of golden sand transported from Hainan Island. The beach occupies 790,000 square meters, including a seaside forest. This project cost about 29 million RMB in total.

\subsection{Projects}

The construction and maintenance costs of beach nourishment are quite high, and renourishment must be performed periodically. In China, at present beach nourishment is still not a main method to protect or maintain recreational beach. Thanks to social-economic development and the improvement of public perception of coastal environment, more and more coastal city governments are able and willing to fund beach restoration. Over the last 2 decades, 16 nourishment projects have been performed and nourished beaches are in planning for many coastal cities, such as Xiamen Island, Quanzhou city in Fujian Province, Shenzhen city in Guangdong province, Beihai city, Qinzhou city in Guangxi province and Sanya city in Hainan Island. The inventory of main nourished beaches shown in Table 2.

\begin{tabular}{|l|c|c|c|c|c|}
\hline \multicolumn{5}{|c|}{ Table 2. Inventory of selected nourished beaches in China (1990-2009) } \\
\hline \multicolumn{1}{|c|}{ Location } & Volume $\left(\mathrm{m}^{3}\right)$ & Sediment size(mm) & Length(m) & Width(m) & Year \\
\hline East Beidaihe beach & 31,100 & $0.5 \sim 0.85$ & 400 & $10 \sim 50$ & 2009 \\
Middle Beidaihe beach & 93,200 & $1.18 \sim 1.70$ & 720 & 30 & 2009 \\
West Beidaihe beach & 139,000 & $0.35 \sim 0.45$ & 680 & 28 & 2008 \\
Luhuitou beach, Sanya & 60,000 & $0.1 \sim 1.5$ & 400 & 80 & 2008 \\
Tianjin Dongjiang port & 120,000 & & 1257 & 165 & 2008 \\
Xiangshan-Changweijiao, Xiamen & 740,000 & $0.3 \sim 0.66$ & 1446 & 80 & 2007 \\
Eastern Gulang Island & 11,400 & $0.8 \sim 1.1$ & 950 & 25 & 2007 \\
Jinshan beach, Shanghai & 46,000 & & 1300 & 50 & 2006 \\
Xiaodonghai, Sanya & 48,000 & 0.5 & 400 & $40 \sim 50$ & 2005 \\
Huiquan Bay, Qingdao & 12,000 & & 500 & 70 & 2003 \\
Xinghai Bay, Dalian & 315,000 & $10 \sim 17$ & 800 & 30 & 1994 \\
Repulse, Hong Kong & 200,000 & & & & 1990 \\
\hline
\end{tabular}

Compared to the nourishment projects in other countries such as Denmark, United Kingdom, Netherland (Hanson et al, 2002) and USA (Dean, 2002), the project scales are relatively small in China with respect to the beach length, volume and investment. The average length of nourished beachs in China is $804 \mathrm{~m}$ and the longest one is only $1447 \mathrm{~m}$ (Xiangshan-Changweijiao beach), and the unit volume is $165.8 \mathrm{~m}^{3} / \mathrm{m}$ in China while $335 \mathrm{~m}^{3} / \mathrm{m}$ in Netherland, $312 \mathrm{~m} / \mathrm{m}$ in United Kingdom and 436 $\mathrm{m}^{3} / \mathrm{m}$ in Spain. Though the projects in China are smaller and less in number than in some western countries, this new technology has shown a rapid development in recent years especially over last 5 years (Figure 16). 


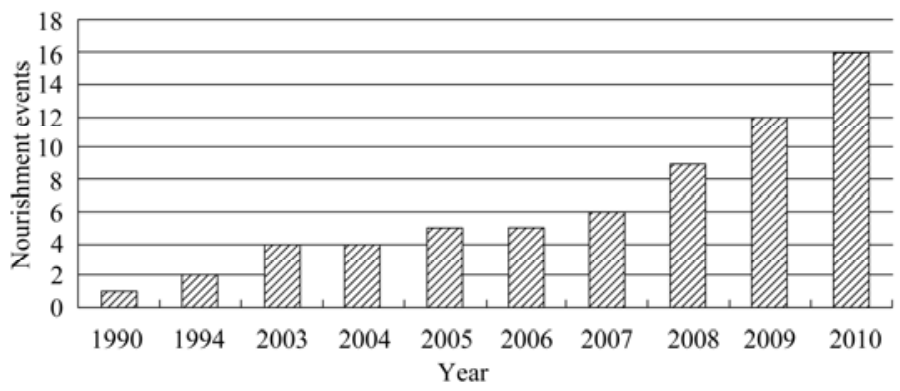

Figure 16. Accumulative total of beach nourishment projects over last 2 decades.

\subsection{Current research}

Through design, monitoring and documentation of these projects, which were performed in different environments and for different purposes, and review of professional literature, experience and knowledge has been gained. Compared to most civil engineering technologies, beach nourishment is fairly new and each site is somewhat unique. Parameters used in the design process are different and the number of parameters that need to be taken into account reflects the degree of varying conditions from site to site. So far only a few projects have been performed, compared to some developed countries. Research is in the exploration stage and there is still much to be learned prior to developing adequate guidance for beach nourishment in China.

Learning the advanced engineering methods and evaluation process from fully developed countries will assist in this effort and the recently completed translation and publication of the Chinese version "Beach Nourishment: Theory and practice (Dean, R. G. 2002)" will also benefit nourishment practice and development in China.

Several beach nourishment research projects are currently underway, the most important one is The National Marine Public Welfare Research Project--“Study on beach nourishment and ecosystem improvement and practice in China” which was lead by TIO (Third Institute of Oceanography, SOA) with the funded amount of 22 million RMB from December 2009 to December 2012. Six scientific institutes and universities are participating in this research. The objectives of this research include: (1) Establishing beach quality classification system; (2) Modeling of wave \& tide driven sediment transport; (3) Study on the technology of beach nourishment; (4) Establishing 4 demonstration sites for beach nourishment; (5) Compiling a manual for beach nourishment and management. Various universities are also cooperating in the manual preparation including the University of Florida, University of Delaware and University of South Florida.

\section{FUTURE PROSPECTS FOR BEACH NOURISHMENT IN CHINA}

Over the last 2 decades, there has been a gradual change from hard to soft coastal defence techniques. Beach nourishment and artificial beaches are widely used as an environmentally acceptable method for beach protection and recreational purposes and it is anticipated that this technology will be more widely used in the future in China. Considering the problems coastal engineers met during project implementation and the issues on beach protection and management, future prospects can be summarised as follows:

Construction of more and larger nourishment projects. Soft engineering implies a new attitude towards nature with the recognition of the value of natural systems (Capobianco and Stive, 1997) and the natural mobility of beaches. Therefore, many local and regional authorities, managers and societies are planning to apply beach nourishment technology in protection and restoration of beaches and dunes. Therefore, more and larger nourishment projects will be performed in near future.

Beach strategy. China suffers from a lack of an overall long-term coastal management strategy and regular monitoring of its coastline. Monitoring programmes provide a wealth of data, which should be properly documented and stored for future analysis and reference. Even though controlling conditions are quite different between various coastal situations, it will be very beneficial to establish a Chinese strategy and a Chinese methodology for beach nourishment and management.

Modeling of wave \& tide driven sediment transport. Numerical models are frequently used at a scientific level to interpret field data. Their use in coastal engineering is no easy task and requires special skills. Their contribution to the design process is nevertheless considered essential. As Hamm et al. (2002) suggested, when properly calibrated and validated, they can provide comparative answers to several alternatives and optimize their efficiency in terms of costs and performance, while providing indications on the uncertainty of coastal responses. 
Post-project evaluation and monitoring. Post-project evaluation is the assessment of a project and normally covers the engineering performance and the environmental and economic aspects of project. The purpose of the evaluation is to enable improvements to be made to all aspects of the planning, design and implementation of future schemes based on the experience learned from completed projects. The basis for this evaluation lies in the monitoring undertaken before and after the implementation.

Beach nourishment manual. In order to support proper decision-making and implementation of beach nourishment, several manuals or guidelines have been published, viz. the Dutch "Manual on artificial beach nourishment”' (CUR, 1987), the German "Empfehlungen für Küstenschutzwerke”, (EAK, 1993), the US book on "Beach Nourishment and Protection"' (NRC, 1995) and the British "'Beach Management Manual”' (CIRIA, 1996 a, b). Additionally, a more specific manual on "Beach Nourishments and Shore Parallel Structures”' was published (CUR, 1997). Each of these sources pays attention to aspects such as problem analysis, nourishment design, implementation, monitoring, environmental impact and evaluation. While these manuals also contain elements of national interest only, they are largely of a generic nature and thus of international value. Considering the rapid development of beach nourishment in China, a manual is needed for providing recommendations for the effective design of future beach nourishment projects.

\section{ACKNOWLEDGMENTS}

This work is funded by The National Marine Public Welfare Research Project, Contract No: 200905008. The project design and execution in the case of Qinhuangdao beach has been supplied by Qinhuangdao Mineral Resource and Hydrogeological Brigade, some data were collected and supplied by Mr. Yu Fan, Third Institute of Oceanography, State Oceanic Administration and Prof. Zhuang Zhenye, Ocean University of China and Dr. Wang Daoru, Hainan Marine Development Plan and Design Institute. The writers would like to thank them for their valuable assistance.

\section{REFERENCES}

Bruun, P. 1954. Coast erosion and the development of beach profiles. Technical Memorandum No. 44, Beach Erosion Board, U.S. Army Corps of Engineers.

Cai, F., Su, X., Liu, J., Li, B., and Lei, G. 2009. Coastal erosion in China under the condition of global climate change and measures for its prevention, Progress in Natural Science, 19, 415-426.

Cao, H., Cai, F., and Chen, F. 2009. Discussion on beach nourishment and ocean tourism of Xiamen coast, Ocean Development and Management, 26(7), 58-62. (In Chinese)

Capobianco, M., and Stive, M.J.F. 1997. Soft protection technologies as a tool for integrated coastal zone management, Proceedings of 3rd International Conference on the Mediterranean Coastal Environment (MEDCOAST '97), Malta, 469-484.

CIRIA. 1996a. Beach Management Manual, Construction Industry Research and Information Association, Report 153, London, United Kingdom

CIRIA. 1996b. Beach recharges material-demand and resources, Construction Industry Research and Information Association, Report 154, London, United Kingdom.

CUR. 1987. Manual on artificial beach nourishment, Center for Civil Engineering Research, codes and specifications, Report 130, Gouda, Netherlands.

CUR. 1997. Beach nourishments and rock structures, Center for Civil Engineering Research, codes and specifications, Report in press, Gouda, Netherlands.

Dean, R. G. 1987. Coastal sediment processes: Toward Engineering Solutions, Proceedings, Coastal Sediments, Proceedings of Coastal Sediments '87, ASCE, 1-24.

Dean, R. G. 2002. Beach nourishment: theory and practice, World Sscientific Press, Singapore.

EAK. 1993. Empfehlungen für die Ausführung von Kstenschutzwerke (Recommendations for the design of coastal structures), Die Ku“ste, Heft 55, Heide, Germany (in German).

Feng, J., Cui, Z., Di, M., Z,W. 1999. The evolution and protection of beach in Qinghuangdao district, Journal of coastal engineering, 18(4), 29-34. (In Chinese)

Hamm, L., Capobianco, M., Dette, H. H., Lechuga, A., Spanhoff, R., and Stive, M. J. F. 2002. A summary of European experience with shore nourishment, Coastal Engineering, 47, 237-264.

Hanson, H., Brampton, A., Capobianco, M., Dette, H.H., Hamm, L., Laustrup, C., Lechuga, A., Spanhoff, R. 2002. Beach nourishment projects, practices, and objectives-a European overview. Coastal Engineering, 47, 81-111.

Ji, X., Zhang, Y., and Zhu, D. 2006. Research development of artificial beach, Marine Geology Letters, 22(7), 21-25. (In Chinese)

Ji, X., Zhang, Y., and Zhu, D. 2007. Evolution of Sanya coast and artificial beach design, Quaternary Sciences, 27(5), 853-860. (In Chinese) 
Leatherman, S. P. 1996. Shoreline stabilization approaches in response to sea level rise: U.S. experience and implications for Pacific Island and Asian nations, Water, Air, \& Soil Pollution, 92,149-157.

NRC/National Research Council, 1995. Beach Nourishment and Protection. Committee on Beach Nourishment and Protection. National Academic Press, Washington, DC, USA

QMRHB (Qinhuangdao Mineral Resource and Hydrogeological Brigade). Design of the emergency nourishment project on the 6th and 9th bathing beach along west Beidaihe coast [R]. 2008.

S.P. Leatherman.1996. Shoreline stabilization approaches in response to sea level rise: U.S. experience and implications for Pacific Island and Asian nations [J]. Water, air, and soil pollution. 92:149-157.

Song, X., Guo, Z., and Chen, S. 2005. The planning and design of artificial beach in the Xinghai Bay, China Civil Engineering Journal, 38(4), 134-140. (In Chinese)

Wang, G., Cai, F., Cao, H., Su, X., and Lei, G. 2009. Study on the Practice and Theory of beach replenishment of Xiangshan-Changweijiao Beach in Xiamen, The Ocean Engineering, 27(3), 66-75. (In Chinese)

Xia, D., Wang, W., Wu, G., Cui, J., and Li, F. 1993. Coastal erosion in China, Acta Geographica Sinica, 48(5), 468-475. (In Chinese)

Yang, Y., and Zhang, J. 2009. Headland control with nourishment to restore the eroded coast, Marine Science Bulletin, 28(3), 92-98. (In Chinese)

Zhang, Y., Liu, S, and Kuang, C. 2008. Numerical study on flow field in nourishment area on west beach of Beidaihe River, Port \& Waterway Engineering, 417(7), 7-13. (In Chinese)

Zhang, Z. 2002. Discussions on development and protection of touring resources of China's sandy beaches from beach nourishment engineering done for American east coast, Marine Geology Letters,18 (3), 23-27. (In Chinese) 